\title{
Ground magnetic investigations in the Godthåbsfjord region, southern West Greenland
}

\section{Thorning}

As a continuation of aeromagnetic surveys (Thorning, 1976, 1977) and subsequent fieldwork (Thorning et al., 1978), ground magnetic investigations were carried out in the Godthåbsfjord region. More detailed work concentrated on specific magnetic anomalies located during the airborne surveys (Mielby \& Svendsen, this report). Fig. 23 indicates the areas visited during summer 1978 .

In Godthåbsfjord work was supported by the GGU cutter Villiaumit enabling some eighty localities to be visited. Twenty more inland localities were reached by helicopter.

Fieldwork concentrated on the mapping of variations in magnetic properties of rocks exposed in the area, by measuring the magnetic susceptibility with an ABEM Kappameter KT-3. A GeoMetrics proton magnetometer G-836 (sensitivity \pm 5 gamma) was used for

Fig. 23. Locations of the geophysical group field work in 1978 .

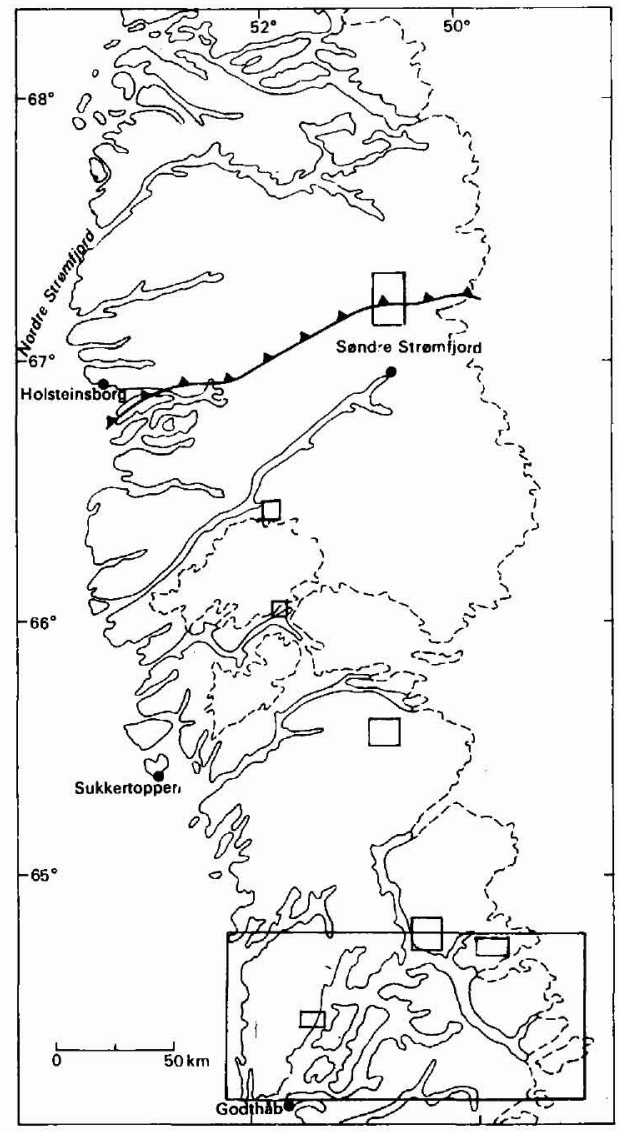


total intensity field profiling at selected localities across geological boundaries in order to qualitatively assess bulk magnetic properties of the rock types involved. Most of the rock types shown by Allaart et al. (1977) were visited several times at different localities.

Aeromagnetic surveys indicate that large parts of the Godthåbsfjord area are magnetically quiet, with exceptions such as Majorqaq, Ilulialik and Ivisârtoq, investigated in more detail by Mielby \& Svendsen (this report). Conclusions on a regional scale however can be summarized as follows.

The dominant rocks types of the magnetically quiet area in Godthåbsfjord (Thorning, 1976) are the Amîtsoq gneiss, the Nuk gneiss and to some extent the Qôrqut granite, all with magnetic susceptibilities in the range $1-10 \times 10^{-3}$ (S. I. units). Magnetically they cannot be distinguished from each other, and frequently local variations within one rock type exceed the differences in susceptibilities between the rock units. A few supracrustal rocks in the area seem to have slightly higher susceptibilities than the gneisses. Within a granulite facies area in the south eastern part of the area high susceptibilities in the order of $10-100 \times 10^{-3}$ (S. I. units) were recorded, again supporting the observation of previous years (Thorning et al., 1978) that there is a correlation between granulite facies rocks and pronounced variations in the aeromagnetic total field data. Similarly, high readings in the eastern part of Nordlandet correlate with major aeromagnetic anomalies distributed along the east coast of Nordlandet. Variations in susceptibility in Nordlandet corresponds to different gneisses, from typical Nuk type gneiss values to very high values in some dioritic gneisses. The granodiorite north of Godthåbsfjord and most of the dykes in the area have high susceptibility values.

Throughout the summer a number of oriented hand samples were collected from various rock types in the area. These will be subjected to laboratory studies of magnetic properties.

A number of localities north of Søndre Strømfjord air base, and a kimberlite locality near the Sukkertoppen Iskappe and the Sarfartôq valley, were also visited.

The information collected during the ground activities of 1976 to 1978 will be compiled into a regional picture of the relationship between magnetic properties and the geology of the areas involved, in support of the aeromagnetic interpretation. No additional fieldwork is contemplated at the present time.

\section{References}

Allaart, J. H., Jensen, S. B., McGregor, V. R. \& Walton, B. J. 1977: Reconnaissance mapping for the 1:500 000 map sheet in the Godthåb-Isua region, southern West Greenland. Rapp. Grønlands geol. Unders. 85, 50-54.

Thorning, L. 1976: Aeromagnetic surveys in southern and central West Greenland between $63^{\circ}$ and $71^{\circ}$ N. Rapp. Gronlands geol. Unders. 80, 61-65.

Thorning, L. 1977: Continuation of the aeromagnetic surveys in southern and central West Greenland between $64^{\circ}$ and $72^{\circ}$ N. Rapp. Grønlands geol. Unders. 85, 34-37.

Thorning, L., Jensen, L. B., Marcussen, C., Mielby, B. S. \& Petersen, S. A. 1978: Geophysical fieldwork on selected aeromagnetic anomalies in central West Greenland. Rapp. Grønlands geol. Unders. 90, 38-42. 